\title{
The Structure of Galombang Dance in Pariangan West Sumatera: A Reconstruction
}

\author{
Afifah Asriati ${ }^{1 *}$, Desfiarni ${ }^{2}$, and Irdhan Epria Darma Putra ${ }^{3}$ \\ ${ }^{123}$ Dance Education Study, Universitas Negeri Padang, Padang, Indonesia \\ *Corresponding author.Email: afifahasriati@yahoo.com
}

\begin{abstract}
The aim of this article is to reconstruct the form and the structure of Tari Galombang (Galombang Dance) in Pariangan, Tanah Datar, Sumatera Barat. The reconstruction was undertaken due to several unique dancing elements tools which no longer be used. To reach the aim of the research, a qualitative study was done through interview and observation including notes and recorded video. Based on the method used, it was found that the structure and the form of Galombang Dance in Pariangan is quite unique. The uniqueness relates to the use of Siriah Gadang as Carano during performing the dance, which will not be seen in any other Galombang Dances found in other areas. This finding calls out researchers' attention to reconstruct the dance.
\end{abstract}

Keywords: Dance, Reconstruction of Dance

\section{INTRODUCTION}

In Minangkabau, there are dances that are said to belong to certain Nagari, such as the Alang Suntiang Panggulu dance from Padang Laweh, the Adok dance from Saningbakar. There are also types of dances that almost exist in every village with different forms, including the Piring dance and the Galombang dance [1]. Galombang dance is a dance that is performed for welcoming guests, and never performed other than for that event, while Piring dance may be performed in various forms of events. Dance generally functions as a means of the ceremony, both religious ceremonies and traditional ceremonies, a means of expressing joy or association, and as a spectacle dance [2](Soedarsono, 1986). Ceremonial dance is a dance specifically used as a means of religious or traditional ceremonies [1]. Because Galombang dance is always used in traditional events, which is often referred to as Alek Nagari (village party) such as for batagak pengulu (crowning new leaders), thus Galombang dance can be classified as a dance that functions as a means of traditional ceremonies. As a means for traditional ceremonies, of course, the Galombang dance has its own rules. Traditionally, dances in Minangkabau performed by men in martial arts style [3], [4], and have never been danced by women, and so did Galombang dance.

Structure means the relationship between the parts of a whole system [5], while the presentation is what is presented. So, in this study what is meant by the structure of the dance presentation is the composition of the presentation of the Galombang dance as a whole from beginning to end, where each part is related to one another in the presentation of the dance.

In its traditional presentation, Galombang dance in Minangkabau has two types; the first, in one-way form, known as Galombang Manyambuik as found in Galombang Duo Baleh and Silek Galombang; while the second, is a form of Galombang dance in two-way directions, as found in Ampalu Pariaman area [6], [7], [1].

In each presentation, after the Galombang moves are performed, the Carano bearer always holds the Carano filled with complete betel and walks towards the guest, then serves the betel to the guest. After that, the guests are headed to the place of the ceremony accompanied by the host. In general, this Galombang dance uses Carano as equipment for waiting for guests. However, unlike the Galombang dance found in jorong Guguak Nagari Pariangan, they do not use Carano, but Siriah Gadang. Siriah Gadang is in the form of "mini houses" on which sirih are placed, as is the case with Carano which is commonly used in other areas. This is one of the uniqueness of the presentation of the Galombang dance in the jorong Guguak Pariangan.

Siriah Gadang, in the presentation of the Galombang dance, only exists in this village. Since previously, it did not use Carano as a place for betel served to the guests but instead, they used Siriah Gadang. This characterizes the dance [8]. Siriah Gadang is used in conjunction with the Galombang dance and will only be presented at every batagak pangulu (coronation of the new pengulu) event and pacu Jawi (cow race). 
Based on the above phenomena, it is necessary to reconstruct the form and the structure of the Galombang dance which uses Siriah Gadang in its presentation. Reconstruction is carried out through gathering past data to be seen and analyzed again in the present. These data are the form and structure of the Galombang dance performances which are very unique. As far as what the researchers got and also based on interviews with resource persons in the Pariangan Nagari, the Galombang dance equipment and tools found in Pariangan cannot be found anywhere else. By carrying out this reconstruction, it will become a more concrete efforts to preserve cultural objects that have not been used anymore.

On the other hand, Nagari Pariangan is a tourism area, which is one of the most beautiful villages in the world. With this nickname, Pariangan certainly has become a tourist destination that is glimpsed by domestic and foreign tourists. As it is known, especially foreign tourists, they want to see the unique and original culture that exists in the places they visit. Therefore, it is necessary to study the structure of the presentation of the Galombang dance in the Pariangan village. Thus, it can attract tourists' attention on how the Galombang dance is structured and presented in Pariangan, West Sumatra.

Minangkabau traditional dance must be following the philosophy and cultural values of the Minangkabau, because dance and music must consider the context of the society in which they are a part [9], and what needs to be saved quickly is cultural wealth that contains high aesthetic, ethical, technical, and spiritual values [10]. In fact, one of the benefits of the reconstruction this Galombang dance is to conserve and preserve this dance, so that its authenticity which has been forgotten so far can be identified and noticed.

By involving elements that are authentic from whatever existed, but at the present time do not or almost do not exist anymore [11], it is very much needed. While Minangkabau people make nature not only a place where they are born, live, develop, and die, but have a philosophical meaning. So that nature becomes the life philosophy of the Minangkabau people which is revealed in Alam Takambang jadi Guru (Nature develops to become Guru) [1] After Islam entered Minangkabau, the customs were strengthened by Adaik Basandi Syarak, Syarak Basandi Kitabullah Adat with syarak jointed, syarak jointed with Kitabulllah (Alquran) [12], and so does the traditional dance in Minangkabau.

\section{MATERIALS AND METHODS}

This research uses qualitative approach. The qualitative methods are used to collect data on the reconstruction of the Galombang dance form and structure. The subject of this research is the Galombang dance in Pariangan village, especially in Jorong Guguak. The data collection technique was done by observing, interviewing, FGD, and documenting with video recordings. The validity of the data was obtained through the triangulation of sources and triangulation of techniques. The data was analyzed by using Miles and Huberman's model

The process of reconstructing the form and structure of the presentation of Galombang dance began with the process of making Siriah Gadang. The manufacture of Siriah Gadang is done by craftsmen who are used to it. At this time, only one person who usually makes Siriah Gadang, named M Sani (79 years old) [8]. Mr. M. Sani learned from his parents who also work as masons [13]. He is a specialist craftsman in making gonjong Rumah Gadang. After that, Galombang dance, which is usually used to welcome guests, is combined with the use of Siriah Gadang in the presentation of the complete Galombang dance.

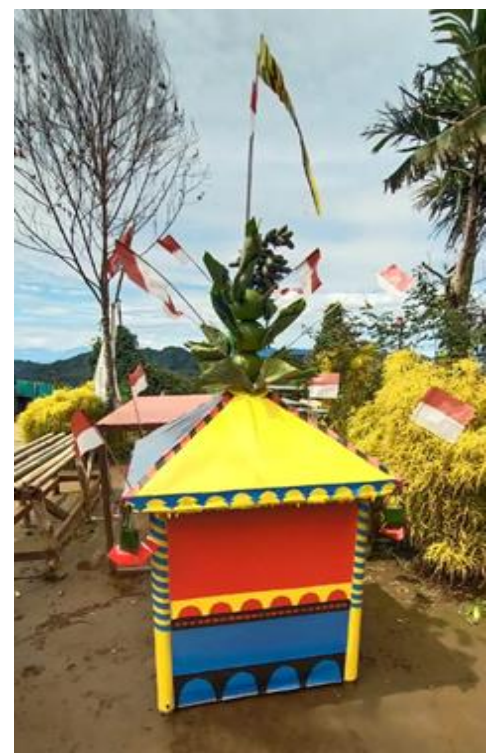

Figure 1. Siriah Gadang

(Documentation: Afifah Asriati, 5th September 2020)

\section{GALOMBANG DANCE PRESENTATION STRUCTURE}

Broadly speaking, the structure of the presentation of Galombang dance in jorong Guguak Nagari Pariangan consists of five parts; first, guests are in front of the Galombang dancers, second, the Galombang 
dancers perform the first Galombang part, the third, guests go to Siriah Gadang place, the guests from the dance tuo, and the guests mancabiak siriah (tearing the betel), fourth, the dancers do the Galombang dance part two and fifth, guests headed to the venue accompanied by talempong pacik music.

Based on the research team's observations about the Galombang dance 5 September 2020 in Jorong Guguak Nagari Pariangan, it can be said that this dance has eight stages in its presentation structure. The structure of the presentation of the eight-stage Galombang dance can be described in more detail as follows: First, new guests are welcome to stand in front of the dancers of Galombang dance as a tribute to the guests who come. Meanwhile, 6 male dancers wearing taluak balango clothes without pockets, lower pisak galembong pants, sisampiang from sarong, and a headband made of batik cloth in the shape of a headband for dubalang, standing two lined at the back, ready to start the dance movement, and Siriah Gadang is placed in the middle of dancers line.

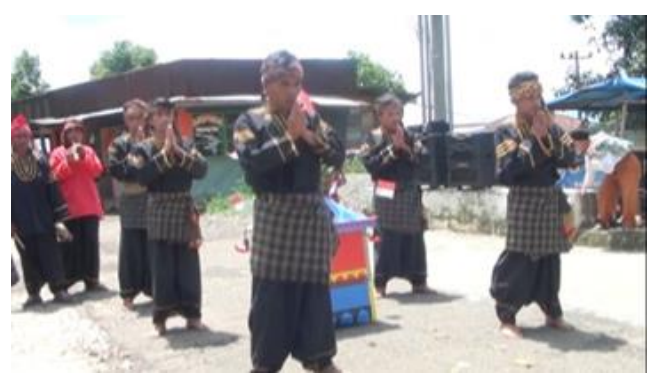

Figure 2. The dancers are getting ready to begin dancing by doing salam sambah move

(Documentation: Afifah Asriati, 5th September 2020)

Second, the dancer performs the first part of the Galombang dance movement, starting from a) the salutation movement, standing straight and the hands are brought together in front of the chest, b) opening steps, the right leg is raised to the knee then stepped sideways by forming a pitunggue motion, after that the feet right step forward, c). Sewai motion, which is the body bending over and the left hand breaking the ground which means asking for forgiveness to the earth and to the sky, d) Mambaok guest movement, the body standing straight and the index finger of the right hand pointing upwards describes bringing guests to the venue. (This movement of rent and mambaok for guests is done twice), g) The motion of the dance, which is the motion of a fight to attack and deflect, there are two kinds of movement, h) the movement of tapuak tingkah, which is to pat or hit Galembong pants. In this Galombang dance, there are four kinds of tapuak tingkah.
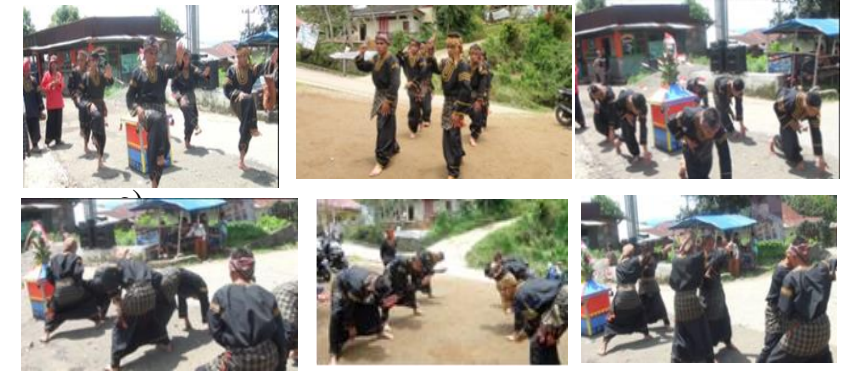

Figure 3. Galombang dance movement part one

(Documentation: Afifah Asriati, 5th September 2020)

After that, the dancers stand face to face in the middle then take a step back so that the guests can walk in the middle of the Galombang dancer line.

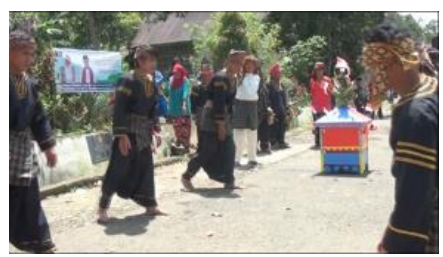

Figure 4.The dancers take a step back to let the guest walk in the dancer line to Siriah Gadang

(Documentation: Afifah Asriati, 5th September 2020)

Third, the guests are welcome to Siriah Gadang and stand in front of Siriah Gadang.

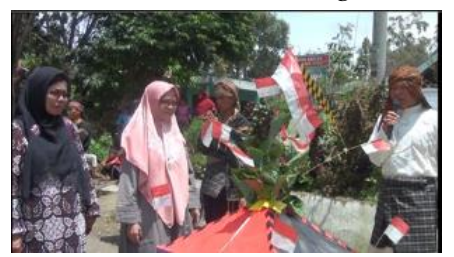

Figure 5. The guest stand in front of Siriah Gadang (Documentation: Afifah Asriati, 5th September 2020)

Fourth, the words of Pasambahan (greeting for guests) from tuo tari (dance teacher), as a welcome greeting to the respected guest [14].

Di ateh puncak lingga puri

Tapampang Siriah Gadang

Maliek siriah galak pinang manari

Maliek ibuk nan alah datang

(Above the peak of castle lingga

Displayed the large betel

Seeing the betel, the nut dance happily

seeing Madam who is coming)

Daga badaga batang sitindiah

Situngka di dalam padi 
Singkatan ambo ka manyiriah

Tando isyaraik baputiah hati

(The sound of sitindiah stem

Situngka is in rice

I want to present the betel

as the sign of our pure heart)

In the last sentence of the pasambahan, the rhyme intends to inviting guests to take the betel that is above the Siriah Gadang.

With the sound of the rhyme:

Rancak lereangnyo gunuang marapi

Lalu turun ka bawah nangko

Kok ibuk makan siriah kami

Nak sanang hati kami basamo

(How beautiful the Merapi Mountain

And it goes down here

If madam is willing to take this betel

We are very pleased then)

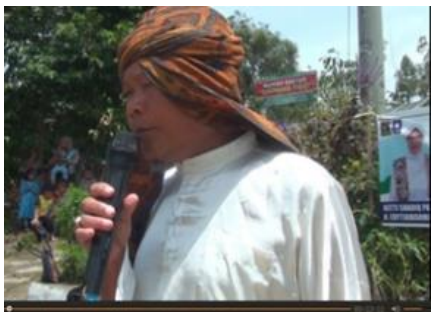

Figure 6. The greeting words from Tuo Tari (dance teacher)

(Documentation: Afifah Asriati, 5th September 2020)

Fifth, guests take the betel above Siriah Gadang. Then they keep standing near Siriah Gadang while watching the second part of the Galombang dance.

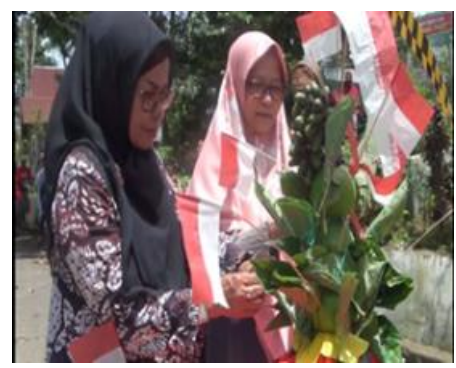

Figure 7. The guests take the betel from Siriah Gadang (Documentation: Afifah Asriati, 5th September 2020)

Sixth, the dancer performs the second part of the Galombang dance. The dancer does panutuik greeting steps, a) lease movements, b) mambaok tamu movements. The movements of the act and the movements of the mambaok tamu are carried out backwards several times until they are approaching Siriah Gadang, c) movements of tapuak tingkah. In the last motion, the dancer performs, d) welcoming motion, which depicts guests being invited to enter the venue with the motion of both arms elbowing in front of the chest and palms stretched out. The first motion is directed to the guest and the second motion is directed to the venue.
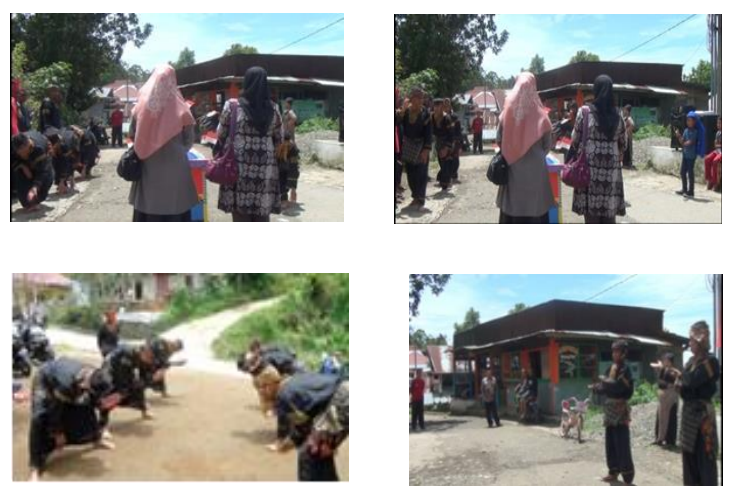

Figur 8. Galombang dance movement part two (Documentation: Afifah Asriati, 5th September 2020)

Seventh, the guests go to the venue while being accompanied by traditional talempong pacik music to accompany guests in the procession to the venue.

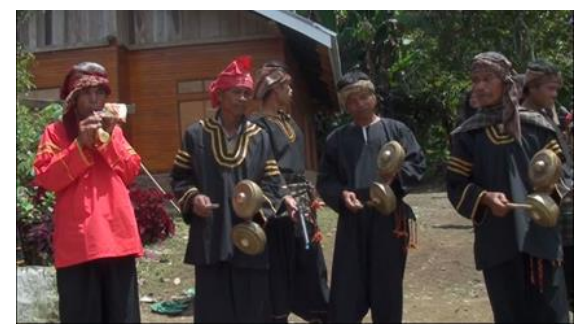

Figure 9. Musician talempong pacik (Documentation: Afifah Asriati, 5th September 2020)

Eighth, the dancer takes Sirih Gadang and brings the Siriah Gadang to the venue, then the Siriah Gadang is placed in front of the guests who sit in the space provided.

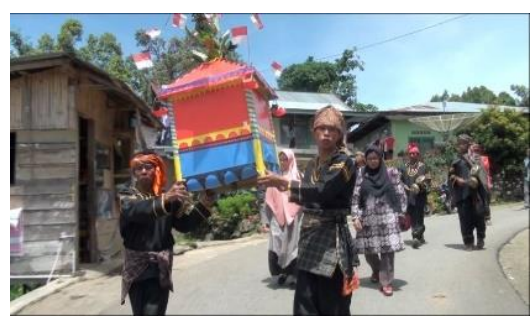

Figure10. Siriah Gadang is brought by dancers accompanied by talempong pacik music

(Documentation: Afifah Asriati, 5th September 2020) 
Based on the findings of the reconstruction results above, there are differences of Galombang dance in pariangan nagari compared to other areas. Galombang dance, generally, has only one part, while Galombang dance movement in Pariangan has two parts. The first part of the initial greeting arrives before the guest goes to the Siriah Gadang place, and the second part after the guest takes betel. Likewise the music, usually at the presentation of the Galombang dance, the music has been played before the Galombang dance movement begins, meaning that the dancer performs a dance accompanied by music, but in this Nagari, the music is played only to accompany guests who are paraded to the venue. This difference makes Galombang dance in Pariangan even more unique and distinctive so that it can attract foreigners and domestic tourists. Galombang dance in jorong Guguak Nagari Pariangan, which uses Siriah Gadang, can only be performed at batagak pangulu and pacu Jawi events. With the reconstruction of the form and structure of the presentation of Galombang with the use of Siriah Gadang, of course, this is an effort to preserve the arts, especially the Galombang dance in Pariangan with its distinctive presentation form, which has not been used for a long time. The reconstruction which is useful for preserving this culture has also been carried out at the Kasunanan Surakarta Hadiningrat Palace. The reconstruction was carried out based on the authority of Gusti Kanjeng Ratu Wandansari [15]. Therefore, reconstruction is an effort to maintain and preserve art to keep growing [16].

\section{CONCLUSION}

It has been found that the presentation structure of the Galombang dance is based on reflections from various credible sources. Galombang dance is used as a means of traditional Alek Nagari ceremonies in the Pariangan village. The relationship between each stage or arrangement of Galombang dance presentation in welcoming guests from start to finish cannot be reversed, because the arrangement must be coherent. The arrangement of each part of the form has been determined in this way. As Sriwulan [17] in his article on the structure of the maanta padi saratuih ceremony in Singkarak, these elements are a system of syntagmatic and paradigmatic relations between events with one another. The implementation must not be reversed because it must be done coherently. Likewise with the structure of the presentation of the Galombang dance in this Pariangan Nagari. If the structure of the presentation of the dance is changed, it will change the meaning of dance or it will no longer have any meaning as a dance for honor as a guest. It is hoped that the people of Jorong Guguak Nagari Pariangan can maintain the results of this reconstruction. and it is hoped that the village government will perform this dance if there are guests who come to the Pariangan village especially to the Jorong Guguak.

\section{ACKNOWLEDGMENTS}

Thanks to Universitas Negeri Padang for Providing PNBP funding for research with this basic research scheme.

\section{REFERENCES}

[1] Navis, Alam Terkembang Jadi Guru (Adat dan Kebudayaan Minangkabau), Jakarta: PT Grafiti, 1984.

[2] Soedarsono, "Pengantar Pengetahuan Komposisi Tari," in Pengetahuan Elemen Tari dan Beberapa Masalah Tari , Jakarta, Direktorat Kesenian Proyek Pengembangaan Kesenian Jakarta Depatemen Peendidikan, 1986, pp. 81-118.

[3] Asriati, A. Kosasih and Desfiarni, "Silat as the Source and Identity of the Minangkabau Ethnic Dance," Harmonia: Journal of Arts Research and Education 19 (2), vol. 19(2), pp. 71-83, 2019.

[4] Asriati, "Minangkabau Dance Form in the Context of ABS-SBK Values)," in in Sixth International Conference on Languages and Arts (ICLA 2017), Padang, 2018.

[5] P. Royce, Antropologi Tari, terjemahanF.X Widaryanto, Bandung: Sunan Ambu Press, 2007.

[6] N. "Nilai-Nilai Kearifan Lokal Melalui Tari Galombang Gaya Sasaran: Studi Sasaran Sebagai Sarana Pendidikan Kultural," Dance \& Theatre Review | volume 2 number 1, May 2019, vol. 2(1), pp. 25-41, 2019.

[7] Soedarsono, Seni Pertunjukan Indonesia: Di Era Globalisasi, Edisi ketiga, Yogyakarta: Gadjah Mada University Press, 2002.

[8] Maizar, Interviewee, Wawancara. [Interview]. 29 Agustus 2020.

[9] Utama, Tari Minangkabau: Dari Pancak dan Pamenan ke Tari Persembahan, Kuala Lumpur: University Malaya, 2017. 
[10]E. Sedyawati, Kebudayaan di Nusantara: Dari Keris, Tor-Tor sampai Industri Budaya, Depok: Komunitas Bambu, 2014.

[11]Djelantik, Seni Pertunjukan di Era Globalisasi, Yogyakarta: Gadjah Mada University Press, 1999.

[12] Amir M.S, Adat Minangkabau: Pola dan Tujuan Hidup Orang Minang, Jakarta Pusat: PT Mutiara Sumber Widya, 1999.

[13] M. Sani, Interviewee, Wawancara. [Interview]. 5 September 2020.

[14] Bunsu, Interviewee, Wawancara. [Interview]. 29 Agustus 2020.
[15] K. P. Herawati and N. S. Prihatinia, "Rekonstruksi Tari Bedhaya Endhol-endhol di Keraton Kasunanan Surakarta Hadiningrat," Panggung No. 2, Juni, vol. 28, pp. 231-243, 2018.

[16]D. Susanti, "Rekonstruksi Tari Zapin Duo Di Kelurahan Teluk Dalam Kecamatan Kuala Kampar Kabupaten Pelalawan Propinsi Riau," Seminar Antar Bangsa : Seni Budaya dan Desain STANSA, pp. 37-46, 2018. 